\title{
EDUKASI PENGGUNAAN PROBIOTIK YANG TEPAT SEBAGAI IMUNOSTIMULAN DI ERA PANDEMI COVID-19
}

\author{
Herlinda Mawardika, \& Ira Oktavia \\ Fakultas Farmasi, Institut Ilmu Kesehatan Bhakti Wiyata Kediri \\ Email: herlinda.mawardika@iik.ac.id, ira.oktavia@iik.ac.id
}

\begin{abstract}
Pandemic COVID-19 is one of the main problems faced by society because it causes a huge impact in the field of health and economy. In overcoming the infection of COVID-19, people are encouraged to apply health protocols such as wearing mask, keeping a distance, washing hands with soap, as well as maintaining the immunity of the body through exercise and the consumption of foods or drinks that are good for health. In addition to herbs, probiotics can be the right choice to be consumed during the pandemic COVID-19. Probiotics are cultures of live microbes that are good for digestive system and have been found to influence the immune system. Probiotics can be obtained from the fermentation products. The objective of this community service was to provide information for the public about the proper use of probiotic to increase the body's immunity in the era of pandemic COVID-19. This activity was carried out by socialization in Duwet Village Malang Regency. The success of the community is determined based on the assessment of participants'questionnaire. The results showed that this community service was going well and achieved the expected goal, socialization increased participants' awareness and understanding of probiotic consumption.
\end{abstract}

Keywords: Probiotics, Immune system, COVID-19

\begin{abstract}
ABSTRAK: Pandemi COVID-19 adalah salah satu masalah utama yang sedang dihadapi masyarakat karena memberikan dampak yang besar di bidang kesehatan maupun perekonomian. Dalam mengatasi infeksi COVID-19, masyarakat dianjurkan untuk menerapkan protokol kesehatan seperti memakai masker, menjaga jarak, cuci tangan dengan sabun, serta menjaga imunitas tubuh melalui olahraga dan konsumsi makanan atau minuman yang baik untuk kesehatan. Selain jamu, probiotik dapat menjadi pilihan yang tepat untuk dikonsumsi selama pandemi COVID-19. Probiotik adalah kultur mikroba hidup yang baik untuk sistem pencernaan dan diketahui berperan dalam mempengaruhi sistem imun tubuh. Probiotik dapat diperoleh dari produk-produk fermentasi. Kegiatan pengabdian masyarakat ini bertujuan memberikan informasi kepaa masyarakat tentang penggunaan probiotik yang tepat untuk peningkatan imunitas tubuh di era pandemi COVID-19. Kegiatan ini dilakukan melalui sosialisasi di Desa Duwet Kabupaten Malang. Keberhasilan pengabdian masyarakat ditentukan dari penilaian kuesioner yang diberikan ke peserta. Hasil evaluasi kegiatan menunjukkan bahwa pengabdian kepada masyarakat ini berlangsung dengan baik dan dapat mencapai tujuan yang diharapkan, yaitu sosialisasi dapat meningkatan pemahaman dan kesadaran peserta untuk mengkonsumsi probiotik.
\end{abstract}

Kata Kunci: Probiotik, Imune system, COVID-19 


\section{PENDAHULUAN}

Pandemi COVID-19 merupakan pandemi penyakit berupa infeksi saluran pernafasan akut yang disebabkan oleh coronavirus 2 (SARS-CoV-2). Penyakit ini telah menyebar ke berbagai negara di dunia, termasuk Indonesia. Jumlah pasien yang dinyatakan positif COVID-19 hingga awal Juli 2020 diketahui mencapai 63.000 orang dan diprediksi akan terus mengalami peningkatan (Satgascovid19, 2020). Pandemi ini memberikan dampak yang besar bagi masyarakat, baik dari segi kesehatan, perekonomian, maupun aktivitas sosial. Dalam mengatasi kondisi tersebut, masyarakat dituntut untuk menjalankan kebiasaan baru atau New Normal.

Bentuk kebiasaan baru yang dianjurkan pemerintah untuk mencegah penularan infeksi COVID-19 adalah beraktivitas dengan menerapkan protokol kesehatan, diantaranya yaitu memakai masker, rajin mencuci tangan dengan sabun atau menggunakan handsanitizer, menjaga jarak, berjemur, dan tidak melakukan perjalanan jarak jauh. Selain itu, tindakan pencegahan yang tidak kalah penting adalah meningkatkan imunitas tubuh melalui konsumsi makanan bergizi, istirahat cukup, dan olahraga secara teratur.

Daya tahan tubuh yang kuat menyebabkan seseorang tidak mudah terinfeksi agen penyakit. Vighi et al (2008) menyebutkan bahwa $70 \%$ sistem imun tubuh dipengaruhi kesehatan sistem pencernaan. Salah satu upaya untuk menjaga kesehatan pencernaan dapat dilakukan dengan konsumsi makanan atau minuman yang mengandung probiotik. Probiotik merupakan kultur hidup, dapat berupa bakteri, khamir, dan kapang yang jika dikonsumsi dalam jumlah yang cukup mampu memberikan pengaruh positif bagi mikrobiota usus. Probiotik penting untuk melawan patogen dalam saluran pencernaan. Umumnya, mikroba probiotik berasal dari golongan bakteri, khamir, dan jamur atau kapang. Mikroba yang berasal dari golongan bakteri umumnya berasal dari kelompok bakteri Lactobacillus spp. Jenis khamir yang biasanya digunakan sebagai probiotik adalah Saccharomyces cerevisiae dan jenis jamur atau kapang meliputi Aspergillus dan Rhyzopus (Winarno, 2020).

Jenis mikroba kelompok bakteri yang manfaat untuk menjaga kseimbangan sistem pencernaan yaitu Lactobacillus casei, Lactobacillus reuteri, Bacillus coagulans, Bifidobacterium dan untuk jenis khamir Saccharomyces boulardii. Probiotik dapat diperoleh dari makanan dan minuman fermentasi seperti yogurt, tempe, kecap, kimchi, susu kefir, dan tape atau dalam bentuk supplement (Winarno, 2020). Di dalam tubuh, probiotik akan bertahan di saluran pencernaan terutama usus besar. Mikroba ini diketahui memiliki beberapa peran penting, yaitu mendukung pertumbuhan bakteri menguntungkan dengan menghambat pertumbuhan bakteri patogen melalui kompetisi ruang dan nutrisi, membantu pencernaan makanan dan absorbsi obat, serta 
memproduksi vitamin yang diperlukan tubuh.

Konsumsi probiotik terbukti dapat mencegah berbagai penyakit, seperti diare, konstipasi, eczema, kolesterol, dan infeksi saluran kemih (Schettle et al, 2013).

Menurut Satuan Tugas Penanganan COVID-19 Malang (2020), Kabupaten Malang termasuk salah satu wilayah di Jawa Timur yang tidak lepas dari kasus COVID-19. Jumlah pasien terkonfirmasi positif COVID-19 mengalami peningkatan pada bulan Juni dan tergolong berisiko tinggi. Berdasarkan hal tersebut, perlu adanya edukasi kepada masyarakat mengenai probiotik dan pemanfaatannya sebagai salah satu upaya pencegahan penularan infeksi COVID-19 di Desa Duwet, Kecamatan Tumpang Kabupaten Malang. Tujuan dari pengabdian ini adalah memberikan informasi kepada masyarakat tentang penggunaan probiotik yang tepat untuk peningkatan imunitas tubuh di era pandemi COVID-19.

\section{METODE PELAKSANAAN}

Kegiatan Pengabdian Masyarakat ini dilaksanakan pada tanggal 24-29 Juli 2020. Adapun tempat pelaksanaan kegiatan di Desa Duwet Kecamatan Tumpang Kabupaten Malang. Pelaksanaan kegiatan pengabdian masyarakat ini menggunakan metode ceramah dan diskusi. Ceramah diperlukan untuk menyampaikan materi sesuai topik yang dipilih, sedangkan diskusi digunakan untuk melihat respon dan mengetahui pemahaman peserta secara lagsung. Pengabdian masyarakat ini dilaksanakan melalui beberapa tahapan.

Tahap pertama diawali dengan pembentukan tim pelaksana kegiatan yang melibatkan mahasiswa. Tahap kedua pengurusan perizinan ke Kepala Desa dan Ketua PONKESDES di Desa Duwet Kecamatan Tumpang Kabupaten Malang yang berperan sebagai mitra pelaksanaan pengabdian masyarakat. Tahap ketiga mempersiapkan materi sosialisasi, dan penyediaan minuman probiotik untuk peserta, serta pelaksanaan kegiatan. Kegiatan ini melibatkan Ibu-Ibu anggota PONKESDES sebagai peserta kegiatan. Pelaksanaan diawali dengan pembagian leaflet dan penyampaian materi terkait probiotik, seperti manfaat, cara konsumsi yang tepat, serta makanan dan minuman yang dapat menjadi sumber probiotik. Pada tahap ini, peserta ditunjukkan contoh produk probiotik secara langsung. Sesi berikutnya adalah diskusi untuk memberikan kesempatan bagi para peserta mendapat informasi yang lebih terkait materi yang disampaikan. Pada akhir kegiatan, dilakukan pembagian minuman probiotik untuk memotivasi peserta dalam mengkonsumsi probiotik secara tepat. Selanjutnya, pemberian kuesioner berisi pertanyaan-pertanyaan seputar materi dilakukan untuk mengetahui seberapa jauh pemahaman peserta sebelum dan sesudah sosialisasi. Indikator keberhasilan dari kegiatan ini ditentukan dari antusias peserta selama pemberian materi dan diskusi, serta 
peningkatan pengetahuan peserta mengenai pemanfaatan probiotik di era pandemi COVID-19.

\section{HASIL DAN PEMBAHASAN}

Kegiatan pengabdian masyarakat ini dilaksanakan oleh tim yang terdiri dari dosen dan mahasiswa. Dosen bertindak sebagai narasumber dalam sosialisasi, sedangkan mahasiswa ikut membantu dalam persiapan hingga pelaksanaan. Dalam rangka mencegah pandemi COVID-19, konsumsi makanan dan minuman dengan nutrisi dan kandungan tertentu sangat dianjurkan untuk memelihara kesehatan tubuh. Selain jamu, konsumsi probiotik dapat menjadi pilihan untuk menunjang imunitas tubuh selama pandemi. Kondisi tubuh yang bugar dengan imunitas kuat akan memperkecil peluang untuk terinfeksi agen penyakit, seperti virus dan bakteri. Disaat jamu menjadi populer karena dipercaya dapat menangkal COVID-19, edukasi terkait probiotik juga perlu dilakukan untuk meningkatkan kebiasaan konsumsi probiotik di masyarakat.

Pelaksanaan kegiatan pengabdian masyarakat ini melibatkan 26 Ibu-Ibu anggota PONKESDES dengan tetap menerapkan protokol kesehatan, seperti menggunaan masker, cuci tangan, menggunakan handsanitizer, dan meminimalkan kontak langsung. Materi disampaikan di beberapa lokasi berbeda untuk mencegah adanya kerumunan warga. Materi yang disampaikan mencakup penjelasan umum tentang probiotik, manfaat, dan cara konsumsi yang tepat. Sebelum mendapatkan materi, sebagian besar peserta kegiatan belum memahami tujuan konsumsi probiotik, waktu konsumsi yang tepat, termasuk perbedaannya dengan antibiotik. Selain itu, peserta juga belum familiar dengan makanan-makanan yang mengandung probiotik. Selama kegiatan berlangsung, peserta mendapat kesempatan berdiskusi untuk memperdalam pemahaman terkait topik yang disampaikan.

Berdasarkan hasil penilaian kuesioner, terdapat peningkatan pengetahuan peserta kegiatan pengabdian masyarakat mengenai probiotik sebesar 55\%. Hal ini dibuktikan dengan nilai posttest yang lebih tinggi dibandingakan nilai pretest. Selain terdapat peningkatan pengetahuan, antusias peserta yang tinggi selama diskusi dapat menjadi indikator keberhasilan dari kegiatan pengabdian masyarakat ini. Berikut adalah diagram hasil pemahaman peserta sebelum dan setelah sosialisai tentang probiotik dan penggunaannya pada Gambar 1, serta proses pelaksanaan kegiatan yang ditunjukkan pada Gambar 2.

Di akhir kegiatan, contoh susu fermentasi dibagikan ke seluruh peserta dengan tujuan meningkatkan motivasi dalam mengkonsumsi probiotik. Probiotik cocok untuk dikonsumsi setiap 


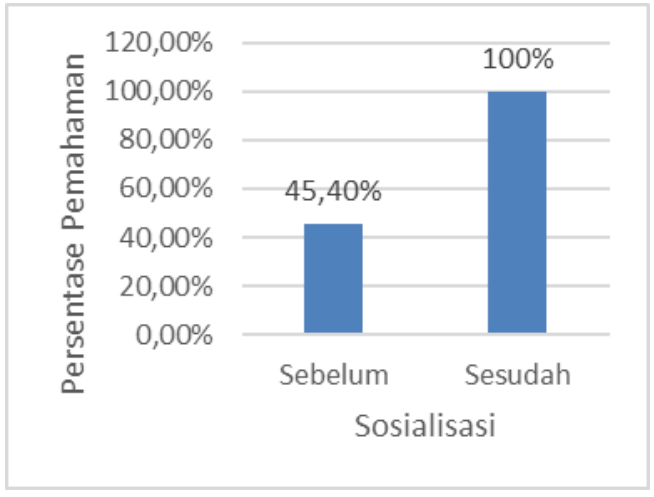

Gambar 1. Tingkat Pemahaman Peserta Sebelum dan Setelah Sosialisasi
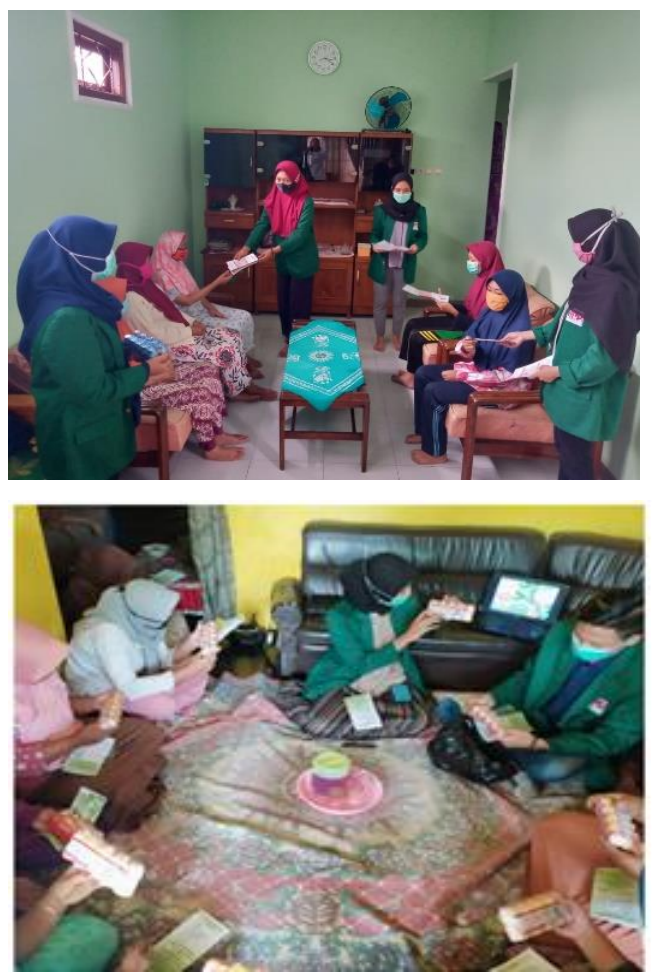

Gambar 2. Penyampaian Materi Sosialisasi dan Pembagian Probiotik

hari untuk menguatkan daya tahan tubuh karena terbukti dapat memodulasi sistem imun humoral dan seluler (Pratiwi dkk., 2020). Probiotik berperan penting dalam menjaga keseimbangan jumlah mikroflora di sistem pencernaan. Bakteri menguntungkan mampu menghambat perkembangan patogen melalui pelepasan senyawa antimikroba dan kompetisi ruang maupun nutrisi. Selain itu, bakteri juga membantu absorbsi makanan dan menghasilkan antioksidan serta vitamin, seperti vitamin $\mathrm{K}$, folat, nisin, tiamin, dan riboflavin (Zommiti et al., 2020). Konsumsi probiotik secara rutin diketahui menghambat kanker, mengontrol kadar kolesterol dalam darah, dan mengatasi konstipasi. Sebuah penelitian menunjukkan bahwa modulasi mikrobiota usus dapat mencegah enteritis dan replikasi virus tahap awal di sel paru sehingga dapat dijadikan alternatif untuk mengatasi COVID-19 (Bradley et al., 2019).

Evaluasi kegiatan yang dilaksanakan masih terbatas pada aspek kognitif, yaitu pada tingkat pemahaman sasaran pengabdian masyarakat. Namun dengan masyarakat memahami, selanjutnya dapat tercapai pula tujuan tidak langsung kegiatan ini, yaitu adanya perubahan sikap dan tingkah laku dengan mengikuti anjuran yang behubungan dengan kesehatan (Maulana, 2007). Penyampaian informasi yang tepat nantinya dapat mendorong peserta untuk mengenal dan mengkonsumsi makanan atau minuman probiotik sebagai upaya menjaga imunitas tubuh di masa pandemi COVID-19.

\section{SIMPULAN}

Kegiatan pengabdian masyarakat ini mampu meningkatkan pengetahuan masyarakat Desa Duwet tentang konsumsi probiotik secara tepat untuk meningkatan imunitas tubuh dalam upaya pencegahan infeksi COVID-19. Sosialisasi selanjutnya dapat melibatkan sasaran yang lebih luas, 
seperti siswa-siswa di sekolah dan di wilayah lain ketika kondisi sudah memungkinkan untuk mengumpulkan peserta dalam jumlah banyak. Kegiatan selanjutnya dapat berupa pelatihan pembuatan makanan atau minuman probiotik yang mudah dan murah untuk diterapkan di rumah. Produk tersebut dapat dikonsumsi sendiri untuk mendukung kesehatan anggota keluarga ataupun dijual sehingga meningkatkan perekonomian masyarakat.

\section{DAFTAR RUJUKAN}

Bradley, KC., Katja, F., Daniel, S., Stefania, C., Miriam, L., Sophia, D., Serge, YF., Peter, S., Andreas, W. 2019. Microbiota-Driven Tonic Interferon Signals in Lung Stromal Cells Protect from Influenza Virus Infection Cell Rep. Vol.28 No.1, hal 245-256

Maulana, H. 2007. Promosi Kesehatan. Jakarta: Buku Kedokteran EGC

Pratiwi, A. dkk. 2020. Pangan Untuk Sistem Imun. Semarang: SCU Knowledge Media

Satgascovid19. 2020. Data Sebaran Covid19. https://covid19.go.id. Diakses 1 Oktober 2020

Satgascovid19. 2020. Data Covid-19. https://satgascovid19.malangkab.go.id Diakses 4 Juni 2020

Schettle, L., PA-C dan Peter A., Lio. 2013. Probiotics: The Search for Bacterial Balance. $\quad$ https://nationaleczema.org/. Diakses 1 November 2020

Vighi, G. F, Marcucci, L., Sensi, G., Di Cara, F. Frati. 2008. Allergy and The Gastrointestinal System. Clinical and
Experimental Immunology. Vol. 153 No.1, hal 3-6

Winarno, F. 2020. Peran Pangan Bagi Kesehatan Mikrobiota Usus Antibodi dan Imunitas. Jakarta: Gramedia Pustaka Utama

Zommiti, M., Feuilloley, M.G.J., Connil, N. 2020. Update of Probiotics in Human World: A Nonstop Source of Benefactions till the End of Time. Microorganisms. Vol 8, No. 12 hal 1907.

https://doi.org/10.3390/microorganisms 8121907. 